\title{
$\beta$-aminoisobutyric Acid (BAIB) Excretion in Urine of Residents of Eight Communities in the States of Michoacón and Oaxaca, Mexico '
}

\author{
GABRIEL W. LASKER, JEFFREY MAST, ${ }^{2}$ AND RICHARD TASHIAN \\ Department of Anatomy, Wayne State University, Detroit, Michigan \\ and Department of Human Genetics, University of Michigan, \\ Ann Arbor, Michigan
}

\begin{abstract}
The ratio of $\beta$-aminoisobutyric acid to neutral amino acids (BAIB/N) in urine was determined in 474 Mexicans from three communities in the state of Michoacán and five in Oaxaca. The frequency curves vary significantly between the three communities in Michoacán and between the two states. The proportion of high excretors (BAIB/N 0.300 ) varies from 14 to $41 \%$ (all intermediate between European white and North American Indian values), but were generally higher in the more "Indian" communities.
\end{abstract}

A non-protein amino acid, $\beta$-aminoisobutyric acid (BAIB), regularly occurs in human urine. The amount excreted varies greatly, but is relatively constant in the same individual and in monozygotic twins (Gartler et al., '55). A high rate of excretion is ascribed to homozygosity of a single recessive gene (Harris, '53). The polymorphism is found in all human populations examined (Blumberg and Gartler, '61) and in chimpanzees (Fooden, '61) and Rhesus monkeys (Robbins and Gavan, '65). The frequency of high excretors varies in different human populations. Since Europeans show a small proportion of high excretors, whereas North American Indians show a high frequency, the examination of this polymorphism in groups of Mexican Mestizo communities with different degrees of "Indianness" was undertaken.

\section{MATERIALS AND METHODS}

Urine specimens were collected in the schools of three communities in the state of Michoacán and from family groups in Miahuatlan and neighboring villages in Oaxaca. Some close relatives are included. In Michoacán, the people of the villages of Cherán and Ahuiran still speak the Tarascan language (cf, Beals, "46) and the people are both physically and culturally more "Indian" than the residents of Paracho $12 \mathrm{~km}$ from Cherán and $3 \mathrm{~km}$ from Ahuiran (Kaplan and Lasker, '53).
In Oaxaca $900 \mathrm{~km}$ southeast of Paracho, the villages around Miahuatlan which were studied are in the Zapotec Indian region of Mexico, but are all considered "Mestizo" although physically the people appear at least as "Indian" as the contemporary Tarascans.

Urine specimens from Paracho were collected in 1962 and from the other communities in 1964. The specimens were preserved with toluene and shipped without refrigeration. Those from Paracho were in one lot and tested at the same time. Those from Ahuiran and Cherán were in another lot, and those from the towns in Oaxaca in a third. The specimens from Ahuiran and Cherán were delayed longer and subjected to more hot weather, but they were tested at the same time as those from Oaxaca and did not appear to be any less satisfactory.

The BAIB in the urine specimens was determined essentially by the method described by Gartler ('61). BAIB was separated on filter paper in an electrophoresis tank (Savant) by one-dimensional high voltage electrophoresis $(2000 \mathrm{v}$ for 30 minutes) in a pH 3.5 buffer. Since specimens could not be collected in the field on a 24-hour basis, the excretion value is calculated as a ratio (BAIB $/ N$ ) of the optical

\footnotetext{
1 Supported in part by U. S. Public Health Service grant GM 09252 .

2 Under a National Institutes of Health Fellowship, General Research Support Grant FR-05384.
} 


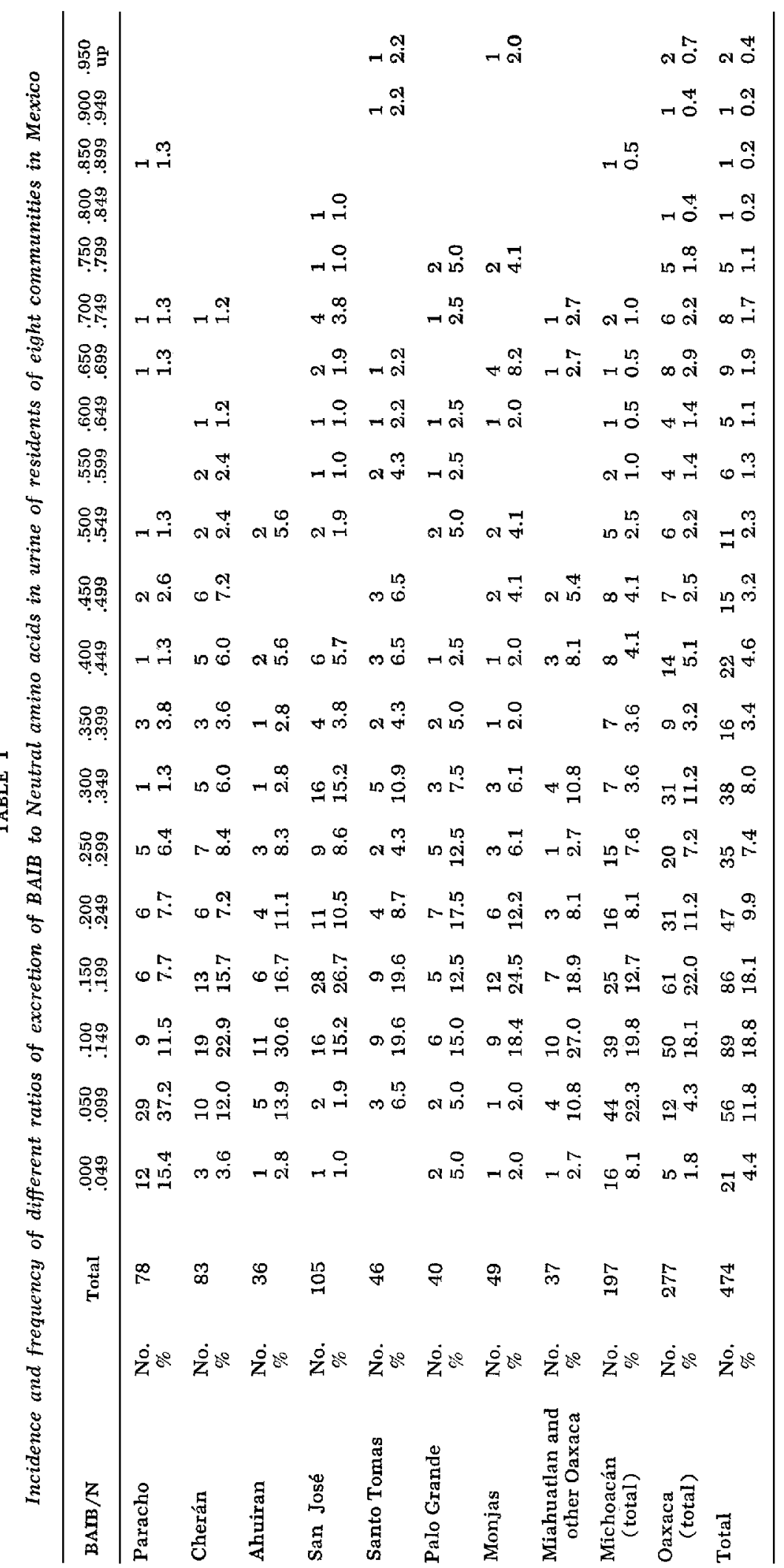


density of the BAIB spot to that of the spot representing the neutral amino acids.

\section{RESULTS}

Table 1 lists the frequency of different levels of the BAIB/ $N$ ratio in the eight subpopulations studied.

The curves of distribution of BAIB $/ N$ were compared by a nonparametric test, the median test. This yields a significant heterogeneity between towns $\left(X^{2}(7)=24.17\right.$, $P<0.01)$ a significant difference between the two states $\left(X^{2}{ }_{(1)}=21.05, P<0.01\right)$ and a significant heterogeneity within the state of Michoacán $\left(\mathrm{X}^{2}{ }_{(2)}=10.68, P<0.01\right)$ but not within Oaxaca $\left(\mathrm{X}_{(4)}{ }=3.89\right.$, $P>0.05$ ).

\section{DISCUSSION}

Using the arbitrary criterion of past studies (a BAIB/N of 0.3 or more being classified as a high excretor), the proportion of high excretors varies between 14 and $41 \%$ (table 2). The weighted average of high excretors is $29.5 \%$ which may be compared on the one hand with $7 \%$ for Italians (Calchi-Novati et al., '53), and $10 \%$ for British (Harris, '53) and American (Blumberg and Gartler, '61) whites. On the other hand it may be compared with values for American Indians of $59 \%$ for Apache (Gartler et al., ' 67 ), 56\% for Athabascans (Allison et al., '59), 50\% in Pima and Papago (Blumberg and Gartler, '61) and 59.7\% for Xavante (Tashian et al., '67). A figure of $23 \%$ for a small group of "Carib Indians" from Surinam (Blumberg and Gartler, '61) is difficult to evaluate in the present connection.

Because the high excretors are not separated from the low excretors by a sharp antimode, any sort of gene frequency analysis is highly speculative. However, using the square root of the frequency of high excretors as a model for relative gene frequencies may be suggestive. Thus, if the European ancestors had a frequency of 0.29 for a gene for high excretion of BAIB and the American Indian ancestors had a frequency of 0.74 , then the mixed populations studied in Mexico with gene frequencies from 0.38 to 0.64 with a weighted mean of 0.54 would range from $1 / 5$ to nearly $4 / 5$ "Indian" and would average about $3 / 5$ "Indian" in respect to that gene.
TABLE 2

Proportion of individuals with a $\mathrm{BAIB} / \mathrm{N}$ ratio of 0.300 or more

\begin{tabular}{|c|c|c|c|}
\hline & \multirow{2}{*}{$\begin{array}{c}\text { Number of } \\
\text { individuals } \\
\text { tested }\end{array}$} & \multicolumn{2}{|c|}{ High excretors } \\
\hline & & Number & Percentages \\
\hline Paracho & 78 & 11 & 14.1 \\
\hline Cherán & 83 & 25 & 30.1 \\
\hline Ahuiran & 36 & 6 & 16.7 \\
\hline San José & 105 & 38 & 36.2 \\
\hline Santo Tomas & 46 & 19 & 41.3 \\
\hline Palo Grande & 40 & 13 & 32.5 \\
\hline Monjas & 49 & 17 & $34: 7$ \\
\hline $\begin{array}{l}\text { Miahuatlan } \\
\text { and other }\end{array}$ & & & \\
\hline Oaxaca & 37 & 11 & 29.7 \\
\hline
\end{tabular}

Most of the apparent heterogeneity which we found is due to the generally low levels of BAIB/ $\mathbf{N}$ found in Paracho. Since these runs were done at a different time and by a different technician (albeit on the same equipment and by the technician who trained one of us to do the remainder) the question arises whether the significant differences are spurious. Two arguments speak against this view. First, excluding Paracho there is still a significant difference $\left(X^{2}{ }_{(1)}=5.35, P<0.05\right)$ between the state of Michoacán and the state of Oaxaca. Second, the deviations are in the direction one would have expected on the basis of other information: on the average the people of Paracho are less Indian and more European in respect to all racial characteristics than are the inhabitants of Cherán or Ahuiran, in the opinion of one of us (GL) who has had extensive experience in the region.

Despite difficulties of collection and transportation, BAIB and the neutral amino acids are apparently stable enough and indicative enough of an underlying polymorphism to give potentially useful information concerning mixed populations. Despite proximity, small communities in Mexico may differ in the extent of European versus American Indian percentage and intercommunity variability in the BAIB polymorphism may be one of the more sensitive indicators of these differences. Furthermore, any selective factors working on this polymorphism are unknown and, if they exist, they apparently do not obliterate differences dependent on ancestry (at least not over the span of time involved 
in the Indian-White mixture in these communities in Mexico.

\section{ACKNOWLEDGMENTS}

The specimens collected in schools were secured through the kind cooperation of the following teachers: Profa. Martha Hernandez, Profa. Maria Luisa Galvan, Prof. José Janacua Onchi and Profa. M. Guadalupe Diaz Huipe. The very helpful technical assistance of Miss Margaret Mann is also gratefully acknowledged.

\section{LITERATURE CITED}

Allison, A. C., B. S. Blumberg and S. M. Gartler 1959 Urinary excretion of beta-amino-isobutyric acid in Eskimo and Indian populations of Alaska. Nature, 183: 118-119.

Beals, Ralph L. 1946 Cheran: A Sierra Tarascan Village. Smithsonian Institute. Institute of Social Anthropology. Publication no. 2, Washington.

Blumberg, B. S., and S. M. Gartler 1961 The urinary excretion of beta-amino-isobutyric acid in Pacific populations. Human Biology, 33: 355-362.

Calchi-Novati, C., R. Ceppellini, I. Blancho, E. Silvestroni and $H$. Harris 1953 Beta-aminoisobutyric acid in excretion in urine. A family study in an Italian population. Ann. Eugen., 18: 335-336.

Fooden, J. 1961 Urinary amino acids of nonhuman primates. Zool., 46: 167-180.

Gartler, S. M. 1961 Urinary amino acids. In; Genetical Variation in Human Populations, G. A. Harrison, ed. Pergamon Press Inc., N. Y., pp, 62-78.

Gartler, S. M., T. Dobzhansky and H. K. Berry 1955 Chromatographic studies on urinary excretion patterns in monozygotic and dizygotic twins. II. Heritability of the excretion rates of certain substances. Am. J. Human Genet., 7; 108-121.

Harris, H. 1953 Family studies on the urinary excretion of beta-amino-isobutyric acid. Ann. Eugen., 18: 43-49.

Kaplan, B., and G. W. Lasker 1953 Ethnic Identification in an Indian Mestizo community. Phylon, 14: 179-190.

Robbins, R. C., and J. A. Gavan 1965 Influence of diet on the qualitative amino acid patterns in the urine of rhesus monkeys (Macaca mulatta). Human Biol., 37: 137-147.

Tashian, R. E., G. J. Brewer, H. Lehmann, D. A. Davis and D. L. Rucknagel 1967 Further studies on the Xavante Indians: V. Genetic variability in some serum and erythrocyte enzymes, hemoglobin, and the urinary excretion of $\beta$-amino-isobutyric acid. Am. J. Human Genet., 19: 524-531. 